Vol.2 No. 3-December 2021

\title{
Assessment of Knowledge, Attitude and Practices towards Gender Equality in Achieving SDG5
}

\author{
Maliha Jahan \\ Bachelor of Economics Program, Specialization of Development Studies, Faculty of Business and \\ Economics, University of Malaya, Kuala Lumpur, Malaysia. \\ maliha.papri@gmail.com
}

\begin{abstract}
This research was conducted to determine the awareness level of the students' at the University of Malaya (UM) towards gender equality in achieving SDG5. A set of survey questionnaire established on Knowledge, Attitude, and Practices (KAP) was distributed through an online Google survey form to all UM students', and 123 responses were collected to evaluate the awareness level (95\% confidence interval with $\pm 5 \%$ margin of error). Data analysis was conducted through SPSS software. The results revealed that the respondents have a higher knowledge level with lower attitude and practices levels. Spearman's Rho coefficient correlation was used to evaluate the relationship level within variables (between knowledge and practices and attitude and practices). The results reported a weak positive correlation within knowledge and practice levels $(r=.275, N=123, p=.00)$ and a very strong positive correlation within attitude and practice levels $(r=.789, \mathrm{~N}=123, \mathrm{p}=.00)$.
\end{abstract}

Keywords: gender equality, SDG5, women empowerment, university, students.

\section{ARTICLE INFO}

Received: October 6, 2021

Received in revised form: November 30 2021

Accepted: December 26, 2021

doi: 10.46456/jisdep.v2i3.209
JISDeP - The Journal of Indonesia Sustainable Development Planning Published by Centre for Planners' Development, Education, and Training (Pusbindiklatren)

Ministry of National Development Planning/ National Development Planning Agency (Bappenas), Republic of Indonesia
Address: Jalan Proklamasi 70,

Central Jakarta, Indonesia 10320

Phone: +62 $2131928280 / 31928285$

Fax: +62 2131928281

E-mail:

journal.pusbindiklatren@bappenas.go.id

Supported by Indonesian Development Planners Association (PPPI) 


\section{Introduction}

Gender equality is a position wherein the gender of a person will not decide their chances, possibilities, freedoms, and significance in life. Gender equality promotes gender balance where opportunities, allocated duties, assets, decision-making power are equally distributed between men and women. According to the United Nations Entity for Gender Equality and the Empowerment of Women [UN Women] (2019), "There is no nation wherein women have equivalent or higher level of freedoms, opportunities and assets than men." Only a few countries have made improvements towards gender equality. Additionally, challenges for being a woman, being of a different race, class and ability makes it more difficult for women to achieve equal treatment.

In September 2015, the 2030 Agenda for Sustainable Development Goals (SDGs) were accepted officially by the United Nations (UN) Sustainable Development Summit. According to the United Nations General Assembly, the SDGs are an assortment of 17 goals intended to be a diagram to accomplish a superior and more sustainable future for everyone. Achieving gender equality in our society is essential for propelling human advancement, the 'Sustainable Development Goal 5: Gender Equality.' The main objective of this goal is to "achieve gender equality and empower all women and girls." According to United Nations (UN), the advancement of gender equality is critical to all spheres of a civilized society, from lessening poverty to advancing the education, protection, health, prosperity and wellbeing of young boys and girls. This study focuses on the awareness level of university students regarding the global goal, which stands for "gender equality and empowering all women and girls." Results of the study are expected to contribute to raising awareness based on knowledge, attitude, and practices among university students' towards gender equality in achieving SDG5.

\subsection{Background of the Study}

Gender equality signifies that the interests, requirements, and needs of both men and women are being considered, perceiving the diversified communities and that all individuals are allowed to establish their own talents and settle on decisions without the restrictions set by the society based on their respective gender. In this paper, the theory of gender equality is specified as both men and women having equal privileges, obligations, and opportunities for accomplishments.

The study "Framed by gender: How gender inequality persists in the modern world?" by Ridgeway (2011) states, "The perception for gender inequality emerges from reading different social science literature, including economics. It establishes as hierarchical gender relations, with men above women, and women being objectified as inferior and less important exclusively based on their gender." Women are subjected to violence, gender discrimination, exploitation, domestic violence, unequal division of unpaid care, and unequal pay scale among men and women (Williams, 2017). Dasli \& Saricoban (2016) stated that gender inequality is persisting globally, denying women and girls fundamental rights and possibilities. Studies show that every one out of five females aged 15 to 49 is subjected to violence, be it domestic or work-related, sexual harassment in public and workplaces. There are 49 countries that do not hold laws protecting women from sexual abuse and harassment. (Hook, 2010).

SDG5 aims to achieve gender equality and empower all girls and women. The primary target of this specific goal is to "end all structures of discrimination and violence against all women and girls." While this is creditable, there is no global overview of data on legal frameworks that end discrimination based on gender. So, there are no specific ways to define the progress of reaching this target. About 53 out of 231 SDG indicators refer to women, girls, and gender. UN Women found no globally established theories or techniques for 23 out of these 53 gender-related indicators. Gender inequality continues worldwide, depriving girls and women of their fundamental rights and possibilities. Still, in recent days, one in every three young girls has encountered female genital mutilation (FGM), and one out of five young girls are forced to get married while they are still kids. One out of four young girls aged $15-19$ years is neither educated, employed, nor trained compared to one out of ten young boys. Furthermore, young girls account for three out of four HIV infections among teenagers aged 10-19 years in developing countries. About four out of ten young girls are beaten by their husbands per year globally, and about 35\% of women aged between 15-49 years have experienced physical and sexual brutality worldwide.

Gender equality is a fundamental human need, and at the same time, it is crucial to achieving global sustainable development. It is a pre-condition for poverty reduction and development advancement. Likewise, accomplishing gender equality is critical for global sustainable development. Among all spheres of social aspects, the jobs of men and women are socially formulated. However, in everyday lives, gender 
inequalities obstruct the advancement of women in every sphere of their life. Women have been only an epitome of the family for decades, and they were tortured and ignored in most parts of the world and still are. Gender inequality represents the absence of women's empowerment in society and the mindset of people, which is a huge barrier to sustainable development. Education about gender equality and neutrality is crucial for the youth if a country wants to achieve sustainable development (Arora-Jonsson et al., 2019). This can be only be achieved if women do not suffer from discrimination and achieve opportunities. Approximately 1.4 billion girls and women are victims of inequality, violence, discrimination, and sexism, even if many governments claim to have taken action (Sen, 2019).

Figure 1 illustrates that the average wage gap in OECD (The Organization for Economic Co-operation and Development) nations are shutting yet at an extremely slower rate. A decade ago, it was $14.5 \%$ and currently is at $13.5 \%$. Furthermore, it has diminished by only 1 percentage point in 10 years. This order is steady with Executive Survey trends, which found out that in OECD nations, the equal wage for comparable work has expanded by around 2 percentage points in 10 years. Gender parity is a factual measure that analyzes a specific indicator among women i.e. average pay, to a similar indicator among men. World Economic Forum (2019) stated that it would take about an additional 100 years (99.5 years to be exact) to achieve global gender parity. Moreover, about $10 \%$ of young girls globally aged between 15-24 years are uneducated. Focusing on illiteracy matter, the report depicts underdeveloped and developing nations where the educational enrollment of girls and women across the educational board is very low. Along the way, this has a critical impact on women's economic participation and opportunities.

- wage equality for similar work (OECD countries) = median wage gap

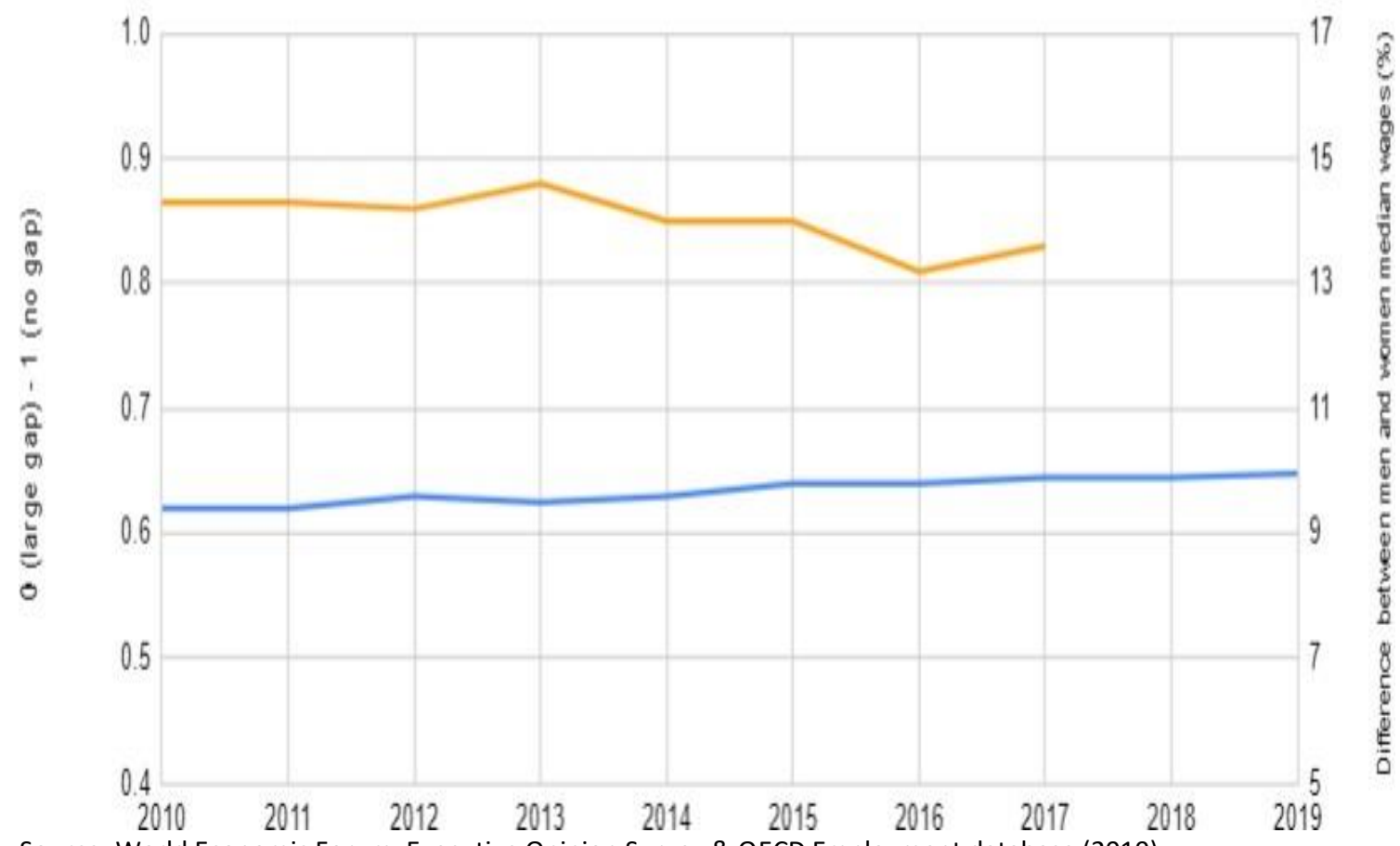

Source: World Economic Forum, Executive Opinion Survey \& OECD Employment database (2019).

Figure 1: Wage gap between men and women, OECD countries (2010-2019)

Compared to the previous Millennium Development Goals (MDGs), the present Sustainable Development Goals (SDGs) are more determined in opportunities and focus on global coverage. Millennium Development Goal-3 especially targeted on "promoting gender equality and empowering women." Numerous aspects of the targeted goals required further efforts. The SDGs eventually succeeded the MDGs and guided the worldwide way of sustainable development after 2015. The SDGs 
were outlined to re-establish the MDGs as the global goals to handle social, political, financial, and environmental issues faced by people worldwide.

SDG5 is primarily centered on " achieving gender equality and empowering all women and girls." Rather than the hierarchical approaches of the MDGs, SDG5 focuses on securing more voices of women within the process of addressing gender-related issues. New perspectives like negligence of women's values, sexual and reproductive rights, sexual assaults, and domestic violence were brought to the limelight. Their focus was to end poverty, transform all lives, and protect the planet. The SDGs are a striving step to bring the view of sustainability upon the people in places that have never been achieved before, yet implementation of the changes among the people is a major concern.

Women empowerment is the first step to gender equality in achieving SDG5. Empowerment of women means giving them marital, cultural, and educational means that they can make their own decisions taking control of the fact that they have their own life. According to Gupta et al. (2019), the only way to achieve women empowerment is by reducing poverty, crisis prevention and recovery, democratic governance, and sustainable and environmental development. Women have an actual voice in all the institutions of governance, from civil service to the judiciary and even from the private sector to civil society (Subašić et al., 2018). Women can participate with men in public speaking and decision-making activities and influence others in society to speak up too. They are making societal changes that will determine the future of their nations and families (Vyas-Doorgapersad, 2018).

Empowerment also refers to empowering women politically, socially, and economically to achieve sustainable development goals. Women's economic empowerment is the equal distribution in the employment sector, administrative, and organizational between men and women and relative distribution in income and wages of women compared to men (Kitada \& Bhirugnath- Bhookhun, 2019). Social empowerment indicates women and girls and their health aspects. It also includes the government proposals on women and girls' mental and physical health. According to Darmstadt et al., (2019), educational empowerment relates to mitigating unequal educational systems in any institution and government providing scholarships to girls and women. Economic empowerment has strengthened women to have a better livelihood without depending on the male gender and reduced the percentage of domestic abuse and violence on women by partners or non-partners (UN Women, 2019).

Figure 2 shows that UN Sustainable Development Goal-5 has nine targets and fourteen indicators. Every target and indicator of SDG5 tries to pursue the primary objective of genuine and sustainable gender equity among all parts of women's and girls' lives. The targets include eliminating gender discrimination, eradicating forced marriages, honor killings, sexual assaults, and domestic violence against women and girls and guaranteeing women's equivalent opportunities for participation in leadership and global sexual and reproductive rights. In Malaysia, the journey to sustainable development has initiated since the 1970s, along with the introduction of New Economic Policy (NEP). The main focus of this policy is to obliterate poverty and modify the social structure in order to restructure social imbalance.

However, the Malaysian Plans have portrayed various governmental plans and initiatives to attain sustainable development, especially SDG-5 or gender equality. Achieving gender equality and SDG5, society requires to empower women, not particularly in the educational or political sector alone, but as a whole, it is empowering women in every aspect of society possible. Malaysia has multiple policies and rules regarding women empowerment, such as establishing Technical Working Groups and Interagency Planning Groups that address gender inequality, legislations, and regulations and implementing improvements for women and girls.

Malaysia was one of 43 countries that presented a Voluntary National Review (VNR) of its SDG progress at the session of 2017 of the High-Level Political Forum (HLPF) on Sustainable Development Goals. During the VNR presentation, Malaysia highlighted its formulation of a National SDG Roadmap to guide SDG implementation. Malaysia has built a prominent development towards gender equality and empowerment of women. In 2001, under the Federal Constitution, the Malaysian supreme law, Article $8(2)$, was modified to end gender discrimination." The main objective of this law was to bring about higher consistent and objective-centered projects to coordinate each woman in development and additionally to promote their position in the society. 


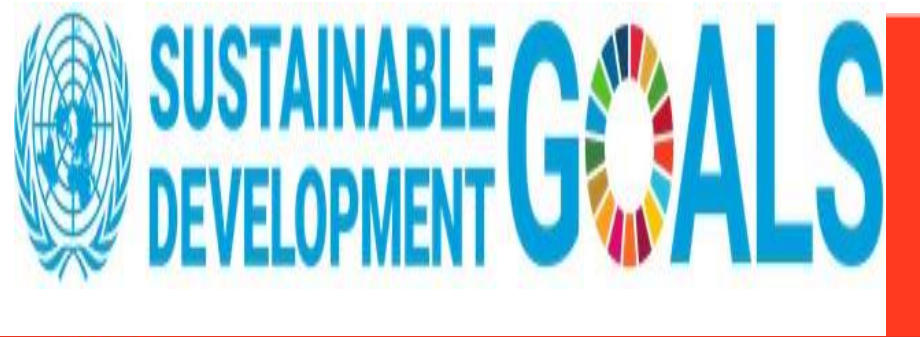

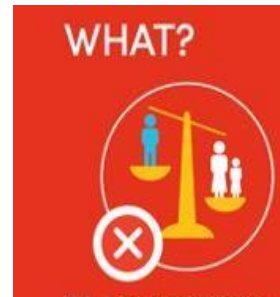

5.1 End discrimination against all women and girls

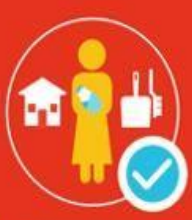

5.4 Recognize and value unpaid care and domestic work

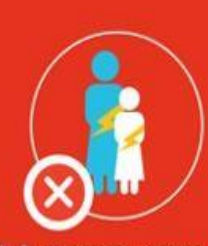

5.2 Eliminate violence against women against wome
and girls

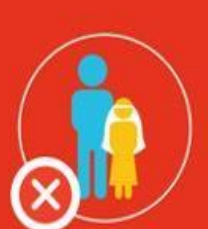

5.3 Eliminate all harmful practices such as child marriage

Source: UN Sustainable Development Goal-5: Gender Equality.

Figure 2: UN SDG5 Specific Targets and Indicators

Malaysia had established numerous international accords, which manifests the country's commitment to guaranteeing the protection of women and girls' rights. The government of Malaysia has taken multiple policies for women empowerment, and studies have shown that every four out of nine women have a need for these policies working in an organization or institution (Montiel, 2018). "The Sexual Offences Against Children Act 2017" had been sanctioned additionally to shield children, especially to protect female children from any harmful practice. Thus, it is necessary to involve young people, especially young students of a country, to achieve the gender equality-related goals faster because they are the future leaders who are responsible for a sustainable planet. As the government considers, education is the first step to demolish gender inequality. Therefore, the government ensures that girls and women could have equal access to education (Akinsemolu, 2018).

The government of Malaysia has planned to gather timely data on the development and on the implemented plans in action to reduce inequality in the society (Kusakabe, 2017). However, though the government has faced various challenges related to this, Malaysia has recognized the concept of sustainable development and applied the concept within the vision, mission, plans, and other policies (Musa \& Husin, 2018). The world is trying to achieve gender equality and women empowerment for sustainable growth in society; women and children are still suffering from discrimination, ignorance, and violence. Psaki et al., (2018) expressed that women are part of a society where one side is trying to empower them; the other is torturing and demeaning them. The Malaysian government focuses on demolishing institutionalized discrimination against women in the country (Franco et al., 2019). Additionally, they invest in women's welfare and other supports for women, therefore, helps them to achieve gender equality. It also restricts subtle practices like portraying women and young girls in media in a stereotypical manner that indicates gender inequality (Shinbrot et al., 2019).

According to Ilham et al. (2019), university campuses can be imagined as small towns, and it is possible to convert such spaces as habitats for the experimental enactment of a new social and technological paradigm that can work as a center point in managing sustainability. One example is the study of "Perceptions and attitudes towards sustainable development among Malaysian undergraduates" 
by Balakrishnan et al. (2020). The Universiti Kebangsaan Malaysia (UKM) has several courses in the field of Sustainable Development for both bachelors and masters programs. The Universiti Putra Malaysia (UPM) has sustainable development studies for different programs. Moreover, the University of Malaya (UM) offers various sustainable development courses i.e. Gender Development, Sustainable Development Education, Green Economy and Sustainable Development, and Development Economics at the graduate and post-graduate levels. These initiatives by higher education institutions in Malaysia clearly show that these institutions have put effort into addressing issues and emphasizing the importance of gender inequality issues to the students. These kinds of activities and approaches will involve university students in practicing gender equality, while at the same time making them aware of its consequences.

Therefore, it is rational to focus on students' knowledge, attitude, and action towards gender equality. Knowledge is the insights of people about certain topics, such as SDG5 and gender equality. Attitude is what they feel, and practice can result from the feelings and what they tend to do about it. (Kaliyaperumal, 2004). Numerous Knowledge, Attitude, and Practice (KAP) studies have been conducted to identify the awareness level of individuals on sustainability and development, for instance, sustainable consumption among university students (Ahamad \& Arifin, 2018); environmental knowledge, attitude, and practices of students and teachers (Esa, 2010); environmental awareness among secondary school students. According to Sybille (2011), these kinds of studies show not only characteristics of knowledge, attitude, and behaviors but also the perceptions of each person on the content. This can be considered as an educational diagnosis of a community (Kaliyaperumal, 2004). Hence, KAP studies offer a way to measure the awareness levels of certain communities in an effective manner (Ahmad et al., 2015).

\subsection{Problem Statement}

Gender equality is fundamentally connected to Sustainable Development and is critical for the recognition of basic human rights for all. The inclusive objective of gender equality is to develop a society in which women and men can appreciate equal opportunities, rights, and obligations in all aspects of life. Both women and men should also have equal knowledge about gender equality. Higher Educational Institutions are an important place for young adults, both male and female. They start to gather knowledge of the outside world and prepare to walk outside the workplace during that time. Therefore, university students need to have the proper definitive knowledge about gender equality in achieving SDG5.

In Malaysia, to stimulate the actions on the SDG5 within the next few years, significant commitments and contributions from all segments of society, especially from higher learning institutions, are mandatory. Universities not only hold a strong influence on society but also on industries and private sectors. In Malaysia, there are about 20 public universities and a number of private universities and colleges, which can be the medium of supports for the implementation of SDG5 and gender equality related studies through the formation and dissemination of knowledge, attitude, and practices through the way of research, teaching and learning, innovation, governance, and leadership. However, the number of public and private universities and colleges that can support the implementation is very few, impacting university students' knowledge, attitude, and practice towards gender equality and SDG5.

Next, the issues of gender equality are very critical and sensitive among young adults i.e. university students, both male, and female. Nevertheless, very few studies and research were done regarding this issue. Some studies can be found on Sustainable Development; however, the studies regarding SDG5, which particularly stands for "achieving gender equality and empowerment for all women and girls," are scarce. University of Malaya (UM) is the oldest public research university located in Kuala Lumpur, Malaysia, and currently aspires to achieve sustainability agenda.

Moreover, in 2019, UM ranked 34th in the UI Green Metric World University rankings. However, no specific research has been found on the awareness level of SDG5-Gender Equality among students of the University of Malaya (University of Malaya [UM], 2019a). Thus, this study attempts to provide information about the current position of young university students of the University of Malaya on the aspect of awareness (Knowledge, Attitude and Practices) on SDG5 and gender equality and intends to enlighten them about the 2030 agenda, which demands an urgent call for actions to ensure gender equality and empower all women and girls. Gender equality is a fundamental human right and a necessary foundation for a peaceful, prosperous, and sustainable world. 


\subsection{Research Objectives}

1. To evaluate the level of knowledge among students towards gender equality in achieving SDG5.

2. To examine the attitude level of university students regarding gender equality and SDG5.

3. To identify the university students' practice level of gender equality in performing their activities.

\subsection{Significance of the Study}

Equality between men and women exists when both sexes can share equally in the distribution of power, opportunity, and influence. It is important to acknowledge that women and girls possess half of the world's total population and half of its development. Gender equality is a basic human right. If women and girls do not face gender equality, the world does not advance to crucial aspects such as a healthy society, clean water, poverty reduction, quality education, and wellbeing. When the world is examined through gender equality perspectives, the world would swiftly advanced towards modern civilization and be assured that girls and women will have equal possibilities like boys and men in every aspects of society.

However, there are still many steps to be taken as many obstacles for girls and women still continue. The SDG5 studies seek to learn how women and girls are discriminated against within societies and how to put an end to these. From ending violence and exploitation to women empowerment or securing their mental, physical and sexual wellbeing, there are various aspects to target if gender equality and empowerment for all women and girls to be achieved by 2030. Thus, universities need to focus on the knowledge, attitude, and action of young students towards gender equality.

The main importance of this study is to take a micro-step towards young university students, by making them aware of the SDG5, which stands for 'achieving gender equality and empowerment for all women and girls. Knowledge is the insights of people about certain topics, such as SDG5-gender equality. Attitude is then what they feel about gender equality and practice can result from their feelings, what they tend to do about it (Kaliyaperumal, 2004). The Knowledge, Attitude, and Practice (KAP) studies are conducted to identify the awareness level of individuals or students on numerous serious issues such as Sustainable Development Goals and gender equality.

\subsection{Scope of the Study}

The scope of the study has numerous remarks required to be highlighted. First and foremost, the primary objective of this study is to assess the knowledge, attitude, and practice (KAP) level among university students towards gender equality in achieving Sustainable Development Goal-5. Secondly, some research has been done on students' knowledge, attitude, and practice level towards the Sustainable Development Goals (SDGs). However, no research has been particularly done on students' knowledge, attitude, and practices towards SDG5. Thus, by conducting this study, the readers will have an overall idea of how much university students know about gender equality and SDG5, their actions and practices regarding this agenda.

In this study, an online google survey was conducted on all University of Malaya's degree level students (Diploma, Bachelors, Masters, and Ph.D.). Due to the recent Covid-19 pandemic, all students at the University of Malaya had been attending their classes online until further notice. Thus, coping with the Covid-19 situation, this study was only conducted online through a google survey. At first, the total number of enrolled students at the University of Malaya was being identified. After that, a minimum sample size (180 respondents) was set for the study. Then, the online google survey form was distributed through UM's official email system (siswa.um.edu.my) of UM. Later, keeping track of the number of respondents, the online google survey form was distributed through official social media (WhatsApp) groups of UM students of different study sessions, years, and faculties. Approximately three to four weeks were allocated for the respondents to fill up the google survey form.

After collecting data from the respondents (123 respondents), an item validity and reliability test (Cronbach's Alpha internal consistency method) was conducted. Then, the data analysis was being done using SPSS (Statistical Package for Social Sciences) method. The results bear the percentages of students' knowledge, attitude, and practices on SDG5. Lastly, the correlation between students' knowledge and practice, attitude and practice, and cross-tabulation were conducted. This study was inferential, the distribution of the google survey form will be random, and the respondents' information was kept private. In the scope of this study, it is highly hoped to spread awareness among university students towards gender equality in achieving Sustainable Development Goal 5. 


\section{Methodology}

\subsection{Sample Size}

In this study, an online-based google survey was conducted to all students at the University of Malaya (Undergraduate, Postgraduate, and Ph.D. students). Firstly, the total number of enrolled students at the University of Malaya (UM) was identified and set as a targeted population (University of Malaya [UM], 2019b). Next, based on a simple formula in the study of Yamane (Israel, 1992), the minimum sample size (180 respondents) was set. A convenient sampling method was used to distribute the targeted 180 respondents. However, later on, 123 respondents were gathered at a $95 \%$ confidence level at $\pm 5 \%$ margin of error. At first, this study was determined to be conducted by both online and paper-based survey, but due to the recent Covid-19 pandemic, only the online-based google form survey was used. The onlinebased google form survey was distributed through the official email application system circulated to all students at the University of Malaya called SISWA Mail (siswa.um.edu.my). Moreover, the survey forms were also distributed throughout all official social media (WhatsApp) platform groups used by the students at the University of Malaya (UM). The study was inferential, random distribution, and confidential.

\subsection{Item Development}

Based on the previous research papers done by Omisore (2017), Ahamad \& Arifin (2018), and Borges (2019), a Knowledge, Attitude, and Practice (KAP) questionnaire (with a 5-point Likert scale) was designed. The questionnaire consisted of five categories. Category $A$ was about the demographic background of the respondents. Category B, C, and D consisted of knowledge, attitude, and practice among University of Malaya (UM) students regarding gender equality in achieving SDG5. Moreover, Category E consisted of respondents' opinions. The number of items was adjusted following the validity and reliability tests conducted.

2.3 Item Validity and Reliability

Table 1: Reliability Test

\begin{tabular}{ccc}
\hline Variable & Item No. & Cronbach's Alpha \\
\hline Knowledge & 10 & .750 \\
Attitude & 10 & .716 \\
Practice & 10 & .890 \\
Total & 30 & .842
\end{tabular}

Amidst several reliability test techniques, Cronbach's alpha (internal consistency) method was chosen for the analysis. From the performed reliability tests, the variables of UM students' knowledge, attitude, and practices towards gender equality in achieving SGD5 had a fine internal consistency, and the Cronbach's Alpha Coefficient was recorded at 0.842. Moreover, the Cronbach's Alpha values of all variables were also recorded to display the fair internal consistency under the satisfaction level of reliability tests, as illustrated in Table 1.

\subsection{Data Analysis Technique}

The awareness level among UM students' was analyzed by applying a descriptive test using the Statistical Package for Social Sciences (SPSS) software. Spearman's Rho Correlation Coefficient was used for the inferential test to determine the correlations between variables (knowledge and practices \& attitude and practices). The data set within knowledge and practice levels was evaluated by applying rank biserial correlation.

According to Chua (2013), the data set was nominal (knowledge variables) \& ordinal (practice variables); thus, Spearman's correlation coefficient was applied instead. Moreover, Spearman's 
correlation coefficient was applied to evaluate the connection between UM students' attitudes and practice levels (both ordinal data) (Chua, 2013). The correlations were significant at $p<0.01$. The depiction of the r-value of Spearman's Rho Correlation (Dancey \& Reidy, 2004) is presented in Table 2 to demonstrate the level of strength of the relationships among the variables.

Table 2: Interpretation of r value of Spearman's Rho Correlation

\begin{tabular}{ll}
\hline Spearman's Rho & Correlation \\
\hline $0.01-0.19$ & None or very weak relationship \\
$0.20-0.29$ & Meak relationship \\
$0.30-0.39$ & Strong relationship \\
$0.40-0.69$ & Very strong relationship \\
\hline 0.70 &
\end{tabular}

*The descriptor applies for both positive and negative relationships.

\section{Results and Discussion}

\subsection{Descriptive Analysis}

\subsubsection{Students' Demographic Background}

Table 3: Demographic Background of Students

\begin{tabular}{lll}
\hline Variables & Items & Percentage (\%) \\
\hline Gender & Male & 39.8 \\
& Female & 60.2 \\
Age & 21 and under & 30.1 \\
& 22 to 32 & 62.6 \\
& 33 to 43 & 5.7 \\
& 44 and above & 1.6 \\
Level of Education & Diploma & 10.6 \\
& Bachelors & 74.8 \\
& Masters & 8.9 \\
Faculty & PH.D & 5.7 \\
& Science & 37.4 \\
& Non-Science & 62.6 \\
\hline
\end{tabular}

Most of the respondents were female, with a high percentage of $60.2 \%$, and the remaining $39.8 \%$ were male as shown in Table 3. The majority of the students were aged 22 to 32 (62.6\%) and 21 and below (30.1\%). Most of the students were bachelor students (74.8\%). Students' educational background was divided according to science faculty at $37.4 \%$ and non-science faculty at $62.6 \%$. 


\subsubsection{Students' Knowledge towards Gender Equality and SDG5}

Table 4: Percentages of Students' Knowledge

\begin{tabular}{|c|c|c|c|}
\hline No. & Items of Knowledge & Yes (\%) & No (\%) \\
\hline$\overline{\mathrm{K} 1}$ & $\begin{array}{l}\text { I am familiar with the term that "Gender Equality } \\
\text { refers to the situation when men and women enjoy the } \\
\text { same rights and opportunities across all sectors of } \\
\text { society." }\end{array}$ & 91.9 & 8.1 \\
\hline K2 & I have heard about the term "SDG5 or Gender Equality" before. & 72.4 & 27.6 \\
\hline K3 & $\begin{array}{l}\text { I am familiar with the fact that the main target of SDG5 is } \\
\text { "to achieve gender equality and empower all women and } \\
\text { girls" by } 2030 .\end{array}$ & 61.8 & 38.2 \\
\hline K4 & $\begin{array}{l}\text { I am aware that 'Gender Equality' is achieved when the } \\
\text { different behaviours, aspirations and needs of men and } \\
\text { women are equally favoured and valued. }\end{array}$ & 90.2 & 9.8 \\
\hline K5 & $\begin{array}{l}2 / 3 \text { of all children deprived of schools are girls, and } 75 \% \\
\text { of the world's illiterate adults are women. }\end{array}$ & 69.1 & 30.9 \\
\hline K6 & $\begin{array}{l}\text { One in three women around the world are likely to be } \\
\text { victims of gender-based violence in their lifetime. }\end{array}$ & 78.0 & 22.0 \\
\hline K7 & $\begin{array}{l}\text { Gender-based violence is one of the extreme reasons of } \\
\text { physical and mental trauma and deaths of women } \\
\text { globally. }\end{array}$ & 86.2 & 13.8 \\
\hline K8 & Women possess only $21 \%$ of the world's parliamentary seats. & 26.8 & 73.2 \\
\hline K9 & $\begin{array}{l}\text { Due to violence and abuse, there are } 50 \text { Million fewer } \\
\text { women in South Asia today than there should have been. }\end{array}$ & 59.3 & 40.7 \\
\hline K10 & $\begin{array}{l}\text { I am aware of the fact that "SDG5" calls for equal } \\
\text { opportunities for women and men in leadership among all } \\
\text { levels of decision-making. }\end{array}$ & 65.0 & 35.0 \\
\hline
\end{tabular}

The high level of knowledge of UM students is illustrated in Table 4. The majority of the students responded positively with a range of $59.3 \%$ to $91.9 \%$, highlighted in blue color. Most of the students have heard about the issue of gender inequality, and most of them are well aware that there are issues on the gender gap. The highest proportion of positive response (Yes \%) was for item K1 "I am familiar with the term that Gender Equality refers to the situation when men and women enjoy the same rights and opportunities across all sectors of society" at 91.9\%. This suggests that UM students acquire a high level of knowledge about gender equality. 
Additionally, about $90.2 \%$ of respondents positively responded to item K5 (Mölders, 2019) that "two-thirds of all the children in school are girls and 75\% of the illiterate in the world are women." About $86.2 \%$ of them were well aware of item K7 (Thystrup, 2020) that "gender-based violence is one of the biggest causes of physical and mental trauma and death to women worldwide." On the other hand, when they were asked about a correct fact about gender equality in item K8 "women possess only $21 \%$ of the world's parliamentary seats", majority of the respondents wrongly answered "No" (73.2\%), which is highlighted in grey color in Table 4. However, the majority of the UM students positively responded to all the other knowledge questions, which shows their high level of knowledge on gender equality and SDG5.

\subsubsection{Students' Attitude towards Gender Equality and SDG5.}

Table 5: Percentages of Students' Attitude

\begin{tabular}{|c|c|c|c|c|c|c|}
\hline No. & Items of Attitude & $\mathrm{D}(\%)$ & $A(\%)$ & $\mathrm{SA}(\%)$ & & \\
\hline A1 & $\begin{array}{l}\text { I believe in our society, all men and women } \\
\text { should be treated equally in all aspects of life. }\end{array}$ & 2.4 & 4.9 & 9.8 & 13.8 & 69.1 \\
\hline $\mathrm{A} 2$ & $\begin{array}{l}\text { I acknowledge that in our society today, there } \\
\text { are more advantages in being a man than being a } \\
\text { woman. }\end{array}$ & 2.4 & 9.8 & 26.0 & 24.4 & 37.4 \\
\hline $\mathrm{A} 3$ & $\begin{array}{l}\text { Achieving equality between men and women } \\
\text { is important to me personally. }\end{array}$ & 2.4 & 5.7 & 13.8 & 23.6 & 54.5 \\
\hline A4 & $\begin{array}{l}\text { I believe a man who stays home to look afterhis children } \\
\text { is less of a man. }\end{array}$ & 61.8 & 9.8 & 17.9 & 4.1 & 6.5 \\
\hline A5 & $\begin{array}{l}\text { I believe women will not achieve equality, } \\
\text { unless men take actions to support women'srights too. }\end{array}$ & 4.9 & 4.9 & 11.4 & 27.6 & 51.2 \\
\hline A6 & $\begin{array}{l}\text { In general, men are being expected to do toomuch to } \\
\text { support women's equality. }\end{array}$ & 19.5 & 17.9 & 30.9 & 18.7 & 13.0 \\
\hline A7 & $\begin{array}{l}\text { Sexual harassment is seen as the most } \\
\text { important issue faced by women. }\end{array}$ & 1.6 & 4.9 & 11.4 & 14.6 & 67.5 \\
\hline A8 & $\begin{array}{l}\text { I believe that ensuring primary education of } \\
\text { girls' could decrease child mortality. }\end{array}$ & 4.1 & 4.1 & 19.5 & 25.2 & 47.2 \\
\hline A9 & $\begin{array}{l}\text { To me, raising awareness on 'Sustainable } \\
\text { Development Goal 5-Gender Equality' among } \\
\text { the university students is necessary. }\end{array}$ & 1.6 & 1.6 & 15.4 & 23.6 & 57.7 \\
\hline A10 & $\begin{array}{l}\text { I feel basic Gender and Development courses } \\
\text { should be a part of a university's curriculum. }\end{array}$ & 3.3 & 2.4 & 20.3 & 22.0 & 52.0 \\
\hline
\end{tabular}

Note: *SD- Strongly Disagree *D- Disagree *N- Neutral *A- Agree *SA- Strongly Agree

Table 5 shows the level of students' attitude towards gender equality in achieving SDG5. All statements recorded well balanced between negative and positive responses accordingly. The majority of the students responded "Strongly Agree" or "Agree" to the attitude questions. However, few students responded "Strongly Disagree" or "Neutral." The shaded blue color ('Strongly Agree' and 'Agree') and grey color ('Neutral' and 'Strongly Disagree') shows the highest percentage for the attitude questions indicating the students' opinion. The highest proportion of "Strongly Agree" positive responses (69.1\%) from students was for item A1 "I believe in our society, all men and women should be treated equally in all aspects of life." This illustrates that UM students are well aware of the importance of equal rights between all men and women.

Next, in Table 5, the majority of the students (61.8\%) responded "Strongly Disagree" for the attitude question A4, "I believe a man who stays home to look after his children is less of a man." This represents that UM students strongly believe gender equality will be restored when men and women are 
given equal household responsibilities. Moreover, the highest percentage (27.6\%) of "Agree" positive responses from students was for item A5, "I believe women will not achieve equality unless men take actions to support women's rights too." This was followed by $30.9 \%$ of "Neutral" responses for item A6 "In general, men are being expected to do too much to support women's equality." Yet overall, the students presented a positive attitude towards gender equality and SDG5. Similar outcomes were also found in studies like those by Al-Naqbi and Alshannag (2018), Biasutti (2017), Borges (2019), Gündüz (2017), and Keles (2017).

\subsubsection{Students' Practices towards Gender Equality and SDG5}

For the practice level of students, a distinctive scenario is discovered, which is presented in Table 6. The highlighted blue color ('Always' and 'Often') and grey color ('Never') shows the highest percentages of the practice statements to show the opinions of the respondents. The majority of the students responded "Always" and "Often," and only a few of them responded "Never" to the practice questions. The highest proportion of students responded "Always" for the practice statement P5 "I give equal importance to all my classmates, friends, teachers, family members regardless their sex, sexual orientation, gender identity, or expression," with 64.2\%. Followed by P6 "I do not make comments that ridicule, demean or humiliate regardless their sex, sexual orientation, gender identity, or expression" (58.5\%); P4 "I treat people of all gender equally" (56.9) and P7 "I do not refuse to do a certain task that is 'specific gender based' task according to the society" (42.3\%). Every student must make these critical commitments to achieve gender equality and SDG5.

Furthermore, when students were asked if they have taken courses related to SDG5 and gender equality (P8), a majority of students responded that they 'Always' (30.1\%) and 'Never' (27.6\%) do. Moreover, the majority of students responded 'Always' (25.2\%) and 'Never' (27.6\%) for item P9 "I participate in events (Such as seminars, talks, workshops that relate to SDG5 and gender equality". This is followed by item P10 "I talk about 'SDG5 and gender equality with my classmates, friends, teachers, and family" (Always $=22.8 \%$, Never= 23.6\%). Yet overall, Table 6 demonstrates that most of the UM students have a high level of practice towards gender equality in achieving SDG5.

Table 6: Percentages of Students' Practices

\begin{tabular}{|c|c|c|c|c|c|c|}
\hline No. & Items of Practices & $N(\%)$ & $R(\%)$ & $S(\%)$ & $O(\%)$ & $A(\%)$ \\
\hline P1 & $\begin{array}{l}\text { I stay alert for any gender based violence (i.e. } \\
\text { sexual, physical, domestic harassment or } \\
\text { abuse) happening around me. }\end{array}$ & 0 & 14.9 & 18.7 & 35.8 & 40.7 \\
\hline P2 & $\begin{array}{l}\text { I raise my voice when someone is being } \\
\text { treated differently just because of their sex, } \\
\text { sexual orientation, gender identity, or } \\
\text { expression. }\end{array}$ & 0.8 & 7.3 & 26.0 & 32.5 & 33.3 \\
\hline P3 & $\begin{array}{l}\text { I report to authority if I am aware of any form of } \\
\text { gender-based discrimination or abuse (i.e. } \\
\text { sexual, physical, domestic harassment or } \\
\text { abuse). }\end{array}$ & 4.9 & 5.7 & 24.4 & 27.6 & 37.4 \\
\hline P4 & I treat people of all gender equally. & 0 & 4.9 & 13.0 & 25.2 & 56.9 \\
\hline P5 & $\begin{array}{l}\text { I give equal importance to all my classmates, } \\
\text { friends, teachers, family members regardless } \\
\text { their sex, sexual orientation, gender identity, or } \\
\text { expression. }\end{array}$ & 0.8 & 6.5 & 13.8 & 14.6 & 64.2 \\
\hline P6 & $\begin{array}{l}\text { I do not make comments that ridicule, demean } \\
\text { or humiliate regardless their sex, sexual } \\
\text { orientation, gender identity, or expression. }\end{array}$ & 1.6 & 4.1 & 17.9 & 17.9 & 58.5 \\
\hline
\end{tabular}




\begin{tabular}{|c|c|c|c|c|c|c|}
\hline No. & Items of Practices & $N(\%)$ & $\mathbf{R}(\%)$ & $S(\%)$ & $\mathrm{O}(\%)$ & $A(\%)$ \\
\hline P7 & $\begin{array}{l}\text { I do not refuse to do a certain task that is } \\
\text { 'specific gender based' task according to the } \\
\text { society. }\end{array}$ & 0.8 & 4.1 & 26.0 & 26.8 & 42.3 \\
\hline P8 & I have taken courses related to SDG5 and gender equality. & 27.6 & 11.4 & 20.3 & 10.6 & 30.1 \\
\hline \multicolumn{2}{|c|}{$\begin{array}{l}\text { P9 I participate in events (Such as, seminars, talks, workshops that } \\
\text { relate to Sustainable Development Goal } 5 \text { and gender } \\
\text { equality. }\end{array}$} & 27.6 & 23.6 & 15.4 & 8.1 & 25.2 \\
\hline $\mathrm{P} 10$ & $\begin{array}{l}\text { I talk about 'Sustainable Development Goal 5and gender } \\
\text { equality with my classmates, friends, teachers and family. }\end{array}$ & 22.8 & 18.7 & 17.9 & 17.1 & 23.6 \\
\hline
\end{tabular}

Note: *N- Never *R- Rarely *S- Sometimes *O-Often *A- Always

\subsection{Correlation Analysis}

Table 7 illustrates a weak positive correlation $(r=.275, N=123, p=.00$ ) between the levels of students' knowledge and practices towards gender equality in achieving SDG5. It also demonstrates that, despite having high knowledge regarding gender equality and SDG5, the practice level of UM students is low. Additionally, Jamilah et al., (2011) expressed that having higher knowledge regarding SDGs has failed to guarantee a higher level of practices amongst students. On the other hand, there is a very strong positive correlation $(r=.789, N=123, p=.00)$ between the levels of students' attitudes and practices towards gender equality in achieving SDG5. It implies that keeping a firm attitude towards gender equality and SDG5 will inspire the UM students to have a higher practice level.

Table 7: Correlation between Knowledge and Practice, and Attitude and Practice

\begin{tabular}{c|c|c|c}
\hline Correlation Between & N & $\begin{array}{c}\text { Spearman's Rho correlation } \\
\text { coefficient }\end{array}$ & Inference \\
\hline Knowledge and Practice & 123 & .275 & Correlated \\
Attitude and Practice & 123 & .789 & Correlated \\
\hline
\end{tabular}

Note: ${ }^{*}$ Correlation is significant at the 0.01 level (2-tailed).

\subsection{Cross Tabulation Analysis}

For this study, cross-tabulation was executed to observe the knowledge, attitude, and practice level of UM students according to numerous variables explicitly. Cross-classification of average positive knowledge of students according to their gender demonstrated that the knowledge level of female students (60.82\%) was much higher than the knowledge level of male students (39.18\%). Moreover, female students (59.35\%) had a higher affirmative attitude than male students $(40.65 \%)$. Likewise, the tendency to practice gender equality and SDG5 was higher amongst female students (53.66\%) than male students (46.34\%). Moreover, UM students of non-science faculties had higher knowledge (science 41.02\%, non-science 58.98\%) and affirmative attitude (science $36.59 \%$, non-science $63.41 \%$ ) and a higher level of practice (science $37.40 \%$, non-science $62.60 \%$ ) towards gender equality and SDG5 than the UM students of science faculties.

The cross-tabulation was also conducted on the students' awareness level (knowledge, attitude, practice) according to their parents' (Father, Mother) educational level. Students who had higher knowledge towards SDG and gender equality (86 students), their parents' educational level was respectively- Fathers (79 Educated, 7 Unschooled) and Mothers (77 Educated, 9 Unschooled). Moreover, students who had affirmative attitude (80 students), their parents' educational level was respectivelyFathers (74 Educated, 6 Unschooled) and Mothers (72 Educated, 8 Unschooled). Furthermore, students who had affirmative attitude (77 students), their parents' educational level was respectively- Fathers (71 
Educated, 6 Unschooled) and Mothers (69 Educated, 8 Unschooled). These variables indicated that students with educated parents (Father and Mother) generally tend to have a higher knowledge, attitude, and practices towards gender equality in achieving SDG5. According to Tatjana (2006), parents are mindful of the activity advancement of their children, but at the same time, they require development education to educate their children properly.

Next, UM students were approached to express their opinion on gender equality and SDG5 (openended questions). The majority of them stated they think providing equal rights, social value, freedom, respect, and responsibilities between all men and women is critical towards gender equality, which is the primary objective of SDG5. The outcomes of another two open-ended questions likewise showed that social media and online websites were the most favored platforms for the students to gain knowledge regarding gender equality and SDG5. In general, the majority of the students remarked that the execution of SDG5 initiatives in Malaysia would restore gender equality between all men and women.

\subsection{Discussion}

From the analysis and results obtained, the study indicated the importance of higher knowledge, attitude, and practice level towards gender equality in achieving SDG5 in Malaysia. There is worldwide awareness developing among young adults (i.e., university students) that gender equality in achieving SDG5 is the foundation of inclusive development. Having a high level of positive knowledge, attitude, and practices will lead students to achieve SDG5. Malaysia has been progressive on the way of women empowerment and gender equalities. Under the Federal Constitution, according to the Malaysian supreme law, Article 8(2) has been corrected to reduce gender discrimination and gender inequality at all stages.

The government of Malaysia has taken several steps through unequal primary education between boys and girls, unequal job description, stopping discrimination in the job sector, and many more towards SDG5. The sustainable development goals aim to ensure that the plans are properly implemented and in motion (Franco et al., 2020). Therefore, providing equal education access and financial freedom and possibilities to both male and female university students is crucial for the Malaysian government to achieve an advanced sustainable economy and improve national wellbeing. For this policy, the Malaysian government will require commitment, fair and successful mechanisms within and across government associations to interpret educational administrations, programs, services, and budgets into specific benefits for both male and female students.

Moreover, the results showed that all institutions and policy regions in Malaysia are counted for gender equality as they all affect young students, yet in a diverse way due to their distinctive situations in educational institutions. Thus, the government of Malaysia should make it compulsory for all students (both science and non-science) to have gender equality and SDG5 related courses in their respective curriculum. Mainstreaming sexual orientation throughout all social institutions should be a fundamental commitment of the Malaysian government. According to United Nations Educational, Scientific and Cultural Organization [UNESCO] (2012), "World Atlas of Gender Equality in Education is the clearest example of this international commitment to global gender equality across and including all levels of education, especially higher educational institutions." According to the Department of Statistics of Malaysia, the country is on the right track to achieve its goals (Sustainable Development Goals, 2019). That is why It is very important to make the university students aware of SDG5 and Gender Equality issues. It is necessary to involve the country's university students to achieve SDG5 faster because they are the future leaders responsible for a sustainable planet.

Furthermore, the analysis of the results illustrated that a reasonable portrayal and participation of male and female students in public life in developing leadership and governance skills are significant towards achieving gender equality in Malaysia. The Ninth Malaysian Plan plays a predominant role in motivating serious sustainable development in Malaysia. Strategic approaches towards sustainable development and to achieve SDG5, which helped the country to ensure the 38th position among 146 nations (Arora-Jonsson et al., 2019). The government should encourage women to participate more in decision-making and be concerned about their participation in the growth and development of the country. Therefore, the analysis depicts that the composition of Malaysian government associations should reflect society to be seen as authentic, capable of conveying fair policies and maintaining gender equality in achieving SDG5 before the law because an effective gender-balanced and diverse policymakers will have the good skill to handle the various requirements of the citizens of a nation. 


\section{Conclusions}

Overall, the awareness level of UM students towards gender equality in achieving SDG5 is high, shown by a significant number of students who possess high knowledge with a positive attitude. Nonetheless, they showed lower performance in practicing gender equality and SDG5. There is a weak correlation between student knowledge and practice level, which indicates that although UM students possess high knowledge about SDGs, their practice level is slightly lower. This can be increased through strategic approaches and intervention programs by the university. However, a very strong positive correlation exists between students' attitudes and practice level. This showed that students would be more driven towards practicing actions aligned with SDG5 and gender equality by having a positive attitude. It should be noted that students' knowledge, attitude, and practice approaches may vary between institutions, and thus other university students in Malaysia may have different levels of awareness towards gender equality and SDG5. On a positive note, several leading universities in Malaysia have already started to include gender equality and SDG5 related courses in their academic structures for both science and non-science students. Therefore, future research could investigate deeper into the barriers of converting knowledge and attitude towards gender equality in achieving SDG5 into practices.

\section{Acknowledgements}

Firstly, I would like to express my deepest gratitude to my supervisor, Dr. Sharifah Muhairah Shahabudin, for her patient guidance and advice throughout the study. Without her responsive assistance and willingness to share knowledge, this paper would never have been possible. I would like to thank my family for their support throughout the process of completing this study. Moreover, I am grateful that the Faculty of Business and Economics, University of Malaya, gave me this opportunity which enabled me to learn and experience the process of conducting this study. Lastly, special thanks to those who ever lend me a helping hand in completing this research paper.

\section{Reference}

Ahmad, J., Noor, S. M., \& Ismail, N. (2015). Investigating Students' Environmental Knowledge, Attitude, Practice and Communication. Asian Social Science, 11(16), 284. https://doi.org/10.5539/ass.v11n16p284

Ahamad, N. R., \& Ariffin, M. (2018). Assessment of knowledge, attitude and practice towards sustainable consumption among university students in Selangor, Malaysia. Sustainable Production and Consumption, 16, 88-98. https://doi.org/10.1016/i.spc.2018.06.006

Al-Naqbi, A., \& Alshannag, Q. (2018). The status of education for sustainable development and sustainability knowledge, attitudes, and behaviors of UAE university students. International Journal of Sustainability in Higher Education, 19(3), 566-588. https://doi.org/10.1108/IJSHE-06-2017-0091

Akinsemolu, A. A. (2018). The role of microorganisms in achieving the sustainable development goals. Journal of cleaner production, 182, 139-155. https://doi.org/10.1016/i.jclepro.2018.02.081

Arora-Jonsson, S., Agarwal, S.,Kurian, P., \& Larson, A. M. (2019). SDG 5: Gender Equality-A Precondition for sustainable forestry. In P. Katila, C. J. P. Colfer, W. de Jong. G. Galloway, P. Pachecho, G. Winkel (Eds.), Sustainable development goals: their impacts on forests and people, 146-177. https://pub.epsilon.slu.se/16554/1/Arora-Jonsson_et_al_200114-2.pdf

Biasutti, M., \& Frate, S. (2017). A validity and reliability study of the attitudes toward sustainable development scale. Environmental Education Research, 23(2), 214-230. https://doi.org/10.1080/13504622.2016.1146660

Borges, F. (2019). Knowledge, Attitudes and Behaviours Concerning Sustainable Development: A Study among Prospective Elementary Teachers. Higher Education Studies, 9(2), 22. https://doi.org/10.5539/hesv9n2p22

Balakrishnan et al. (2020). Perceptions and attitudes towards sustainable development among Malaysian undergraduates. International Journal Higher Education. 9(1), 44-51. https://doi.org/10.5430/ijhe.v9n1p44

Chua, Y. P. (2013). Mastering research statistics. McGraw-Hill Education. 
Dancey, C. and Reidy, J. (2004) Statistics without Maths for Psychology: using SPSS for Windows. Prentice Hall.

Dasli, Y., \& Saricoban, S. (2016). Determination of attitudes on gender: A study on higher education students. European Scientific Journal, 233-239. https://doi.org/10.19044/esj.2016.v12n26p268

Darmstadt, G. L., Heise, L., Gupta, G. R., Henry, S., Cislaghi, B., Greene, M. E., \& Weber, A. M. (2019). Why now for a Series on gender equality, norms, and health? The Lancet, 393(10189), 2374-2377. https://doi.org/10.1016/S0140-6736(19)30985-7

Esa, N. (2010). Environmental knowledge, attitude and practices of student teachers. International Research in Geographical and Environmental Education, 19(1), 39-50. https://doi.org/10.1080/10382040903545534

Franco, I., Saito, O., Vaughter, P., Whereat, J., Kanie, N. (2019). Higher education for sustainable development: actioning the global goals in policy, curriculum and practice. Sustainability Science, 14(6), 1621-1642. https://doi.org/10.1007/s11625-018-0628-4

Franco, I. B., Meruane, P. S., \& Derbyshire, E. (2020). SDG 5 Gender Equality. In I. B. Franco, T. Chatterji, S. Derbyshire, \& J. Tracey (Eds.), actioning the global goal for local impact (pp. 69-83). Springer https://doi.org/10.1007/978-981-32-9927-6

Gündüz, S. (2017). A Research about attitudes and behaviors of university students with having different cultures towards the environment through sustainable development. EURASIA Journal of Mathematics Science and Technology Education, 13(6), 1881-1892. https://doi.org/10.12973/eurasia.2017.01206a

Gupta, G. R., Oomman, N., Grown, C., Conn, K., Hawkes, S., Shawar, Y. R., Equality, G. (2019). Gender Equality and gender norms: framing the opportunities for health. The Lancet, 393 (10190), 25502562. https://doi.org/10.1016/S0140-6736(19)30651-8

Hook, J. L. (2010). Gender inequality in the welfare state: Sex segregation in housework. American Journal of Sociology, 115(5), 1480-1523.

Israel, G. D. (1992). Determining Sample Size. University of Florida Cooperative Extension Service, Institute of Food and Agriculture Sciences.

Ilham, Z., Jamaludin A. A., \& Hakimi, M. I. (2019). Youth for environmental sustainability (YES) Malaysia. $1^{\text {st }}$ Asia-Pacific RCE SDG Youth Challenge 2018 on- Youth for the Goals: Climate Action and Life Below Water.

https://www.westernsydney.edu.au/data/assets/pdf file/0005/1492628/AP SDG Youth Challeng e Report 2018 Final.pdf

Jamilah, H. A., Hasrina, M., Hamidah, A. H., Juliana, A. W. (2011). Pengetahuan, sikap dan amalan masyarakat Malaysia terhadap isu alam sekitar. Akademika, 81 (3), 103-115.

Kaliyaperumal, K. (2004). Guideline for conducting a knowledge, attitude and practice (KAP) study. AECS Illumination, 4(1), 7-9.

Keles, Ö. (2017). Investigation of pre-service science teachers' attitudes towards sustainable environmental education. Higher Education Studies, 3(7), 171-180. https://doi.org/10.5539/hes.v7n3p171

Kusakabe, K. (2017). Analysis 2: SDG5, Gender equality in and through fisheries. Yemaya, (54), 5-6. http://aquaticcommons.org/21415/1/Yemaya_54_article_4_Gender\%20equality.pdf

Kitada, M., \& Bhirugnath-Bhookhun, M. (2019). Beyond business as usual: The role of women professionals in maritime clusters. WMU Journal of Maritime Affairs, 18(4), 639-653. https://doi.org/10.1057/palcomms.2017.23

Montiel, A. V. (2018). Gender equality and big data in the context of the sustainable development goals. Partecipazione e conflitto, 11(2), 544-556. 
Musa, N., \& Husin, A. (2018). Towards gender equality in Malaysia: Legal and policy perspectives [Conference session]. Tun Fatimah Hasyim Women Lead Conference 2018, Putrajaya, Malaysia. https://www.researchgate.net/profile/Nurhafilah_Musa/publication/332751792

Mölders, T. (2019). Rethinking gender: Feminist perspectives on sustainable development goals in the light of (re) productivity. GAIA-Ecological Perspectives for Science and Society, 28(2), 95-99. https://www.ingentaconnect.com/contentone/oekom/gaia/2019/00000028/00000002/art00007? crawler=true\&mimetype=application/pdf

Omisore, A. G., et al. (2017). Awareness and knowledge of the sustainable development goals in a university community in Southwestern Nigeria. Ethiopian Journal of Health Sciences, 27(6), 669-676. https://doi.org/10.4314/ejhs.v27i6.12

Psaki et al. (2018). Measuring gender equality in education: Lessons from trends in 43 countries. Population and Development Review, 117-142. https://www.youthpower.org/sites/default/files/YouthPower/resources/Measuring\%20Gender\%2 OEqualityin\%20Education\%20Lessons\%20fromTrends\%20in\%2043\%20Countries.pdf

Ridgeway, C. (2011). Framed by gender: How gender inequality persists in the modern world. Oxford University Press.

Sybille, G. (2011). The KAP survey model (knowledge, attitude and practices).

Subašić, E., Hardacre, S., Elton, B., Branscombe, N. R., Ryan, M. K., \& Reynolds, K. J. (2018). We for She: Mobilising men and women to act in solidarity for gender equality. Group Processes \& Intergroup Relations, 21(5), 707-724. https://doi.org/10.1177\%2F1368430218763272

Sustainable Development Goals. (2019). Malaysian sustainable development knowledge platform.

Shinbrot, X. A., Wilkins, K., Gretzel, U., \&amp; Bowser, G. (2019). Unlocking women's sustainability leadership potential: Perceptions of contributions and challenges for women in sustainable development. World Development, 119, 120-132. https://doi.org/10.1016/j.worlddev.2019.03.009

Sen, G. (2019). Gender Equality and Women's Empowerment: Feminist Mobilization for the SDGs. Global Policy, 10 (S1), 28-38. https://doi.org/10.1111/1758-5899.12593

Tatjana, M., K. (2006). Semejnoto vospituvanje i socialnoto odnesuvanje na decata, Skopje, pp. 118

Matilov, Naum, (2002), Brak I semejstvo, Skopje, 194-195.

Thystrup, A. G. (2020). Gender-inclusive governance for e-commerce. The Journal of World Investment \& Trade, 21(4), 595-629. https://repository.graduateinstitute.ch/record/296706/files/CTEI-201807_Thystrup.pdf

United Nations Educational, Scientific, and Cultural Organization. (2012). World Atlas on Gender Equality in Education. https://www.macfound.org/media/files/unesco-world-atlas-gender-education.pdf

United Nations Entity for Gender Equality and the Empowerment of Women. (2019). UN Women global database on violence against women.

University of Malaya (2019a). University Malaya living lab achievement report (2019-2020).

University Malaya. (2019b). University Malaya fact sheet.

Vyas-Doorgapersad, S. (2018). Designing measurement instruments for sustainable development goals one, five and nine. African Journal of Public Affairs, 10(3), 118-133. https://journals.co.za/doi/pdf/10.10520/EJC-11496798ad

Williams, M. J. (2017). Analysis 1: SDG5, gender equal fisheries. Yemaya, (54), 2-3. http://aquaticcommons.org/21413/1/Yemaya_54_article_2_Gender\%20equal\%20fisheries.pdf

World Economic Forum. (2019). Global gender gap report 2020 